\title{
DNA BARCODING UNTUK AUTENTIKASI PRODUK HIU SEGAR DARI PERAIRAN NUSA TENGGARA BARAT
}

\author{
Muhammad Alsere Bardian Sahaba ${ }^{\star}$, Asadatun Abdullah, Roni Nugraha \\ Departemen Teknologi Hasil Perikanan, IPB University, Jalan Agatis, Kampus IPB Dramaga 16680 Bogor
}

Diterima: 8 November 2021/Disetujui: 31 Desember 2021

*Korespondensi: alserebardian@gmail.com

Cara sitasi: Sahaba MAB, Abdullah A, Nugraha R. 2021. DNA barcoding untuk autentikasi produk hiu segar dari perairan Nusa Tenggara Barat. Jurnal Pengolahan Hasil Perikanan Indonesia. 24(3):407-414.

\begin{abstract}
Abstrak
Perikanan hiu dan pari di Indonesia, termasuk Tanjung Luar di NTB, menghadapi tantangan besar karena populasi hiu dan pari yang terus menurun. Hiu sangat rentan terhadap penangkapan berlebih dan kepunahan karena faktor seperti kematangan seksual yang lambat dan fekunditas yang rendah. Daging dan sirip hiu umunya diminati konsumen; namun, produk hiu lainnya tidak dicatat secara terpisah dalam statistik perdagangan, sehingga sulit untuk diidentifikasi berdasarkan indikator morfologi. Sebagai alternatifnya dapat menggunakan metode DNA barcoding. Penelitian ini bertujuan untuk mengidentifikasi spesies hiu langka yang terdaftar di CITES yang telah mendarat di pelabuhan NTB menggunakan metode DNA barcoding. Penelitian yang dilakukan meliputi tahap isolasi DNA, amplifikasi DNA, sekuensing dan analisis bioinformatika. Hasil sekuensing DNA dan analisis bioinformatika menunjukkan spesies Sphyrna lewini dan Carcharhinus falciformis teridentifikasi pada sampel dengan tingkat kemiripan 99-100\%. Hasil ini menunjukkan ikan hiu yang termasuk dalam daftar CITES masih kerap ditangkap dan dimanfaatkan, sehingga perlu dilakukan regulasi yang lebih tegas dan transfer pengetahuan kepada masyarakat agar spesies hiu yang tergolong terancam punah dapat dilestarikan.
\end{abstract}

Kata kunci: bioinformatika, CITES, DNA barcoding

\section{DNA Barcoding for Fresh Shark Products Authentication from West Nusa Tenggara Waters}

\begin{abstract}
Shark and ray fisheries in Indonesia, including Tanjung Luar, West Nusa Tenggara, face considerable challenges where shark and ray populations continue to decrease. Sharks are particularly vulnerable to overfishing and extinction due to slow sexual maturity and low fecundity. Shark meat and fin are generally in demand by consumers; however, other shark products are not separately recorded in trade statistics, making them difficult to identify based on morphological indicators. As an alternative, the DNA barcode method can be applied. This study aims to identify rare shark species recorded on CITES that have landed at the port of NTB using the DNA barcoding method. The research includes the stages of DNA isolation, DNA amplification, sequencing and bioinformatics analysis. The results of sequencing and bioinformatics analysis showed Sphyrna lewini and Carcharhinus falciformis DNA species in samples with $99-100 \%$ similarity. These results show that the use of sharks that are included in the CITES list is still often carried out, so it is necessary to implement stricter regulations and transfer public knowledge so that endangered shark species can be preserved.
\end{abstract}

Keyword: bioinformatics, CITES, DNA barcoding 


\section{PENDAHULUAN}

Indonesia adalah negara pemasok hiu dan pari terbanyak di dunia, dengan setiap tahunnya rata-rata memproduksi hiu dan pari tidak kurang 100.000 ton per tahun (Dent dan Clarke 2015, Muttaqin et al. 2018). Saat ini, perikanan hiu dan pari Indonesia, termasuk Tanjung Luar NTB, sangat kritis karena populasi hiu dan pari yang terus menurun, sementara permintaan produk hiu di dalam ataupun luar negeri sangat tinggi. Dalam situasi ini, diperlukan upaya untuk mengintegrasikan pengelolaan perikanan hiu dan pari agar pemanfaatan hiu dan pari di Indonesia dapat terus berlanjut (Simeon et al. 2017).

Daging dan sirip hiu merupakan produk hiu yang paling banyak diminati konsumen; namun, produk hiu lainnya tidak dicatat secara terpisah dalam statistik perdagangan, sehingga sulit untuk dilacak. Hiu sangat rentan punah apabila mengalami penangkapan berlebih karena faktor biologis misalnya kematangan seksual yang lambat, periode kehamilan yang relatif lama, dan fekunditas yang rendah (Ferretti et al. 2010; Bräutigam et al. 2015).

Hasil evaluasi International Union for the Conservation of Nature (IUCN) menunjukkan dari 1.038 spesies hiu dan pari, hampir 20\% dikategorikan sangat terancam punah, terancam punah, atau rentan, dan $12 \%$ lainnya masuk dalam kategori hampir terancam punah (Bräutigam et al. 2015). Tiga belas spesies atau kelompok spesies elasmobranch juga telah dicantumkan dalam daftar Appendix II oleh Convention on International Trade in Endangered Species of Wild Fauna and Flora (CITES), artinya dibutuhkan izin ekspor khusus dalam perdagangan internasional hewan tersebut (CITES 2019). Untuk menegakkan peraturan tersebut perlu dilakukan identifikasi spesies pada produk hiu yang diperdagangkan.

Ahli taksonomi seringkali dapat mengidentifikasi hiu hingga ke tingkat spesies menggunakan indikator morfologi pada spesimen hiu yang masih utuh dan tidak diproses atau belum dilakukan pengolahan. Beberapa sirip hiu juga dapat diidentifikasi dengan cara tersebut; namun, dibutuhkan pelatihan ekstensif dan terkadang sulit untuk teridentifikasi karena terdapat beberapa spesies yang mirip (Hanner et al. 2016; Marshall dan Barone 2016). Untuk mengatasi permasalahan tersebut, autentikasi menggunakan biomolekuler dengan memanfaatkan basa nukleotida atau Deoxyribonucleic Acid (DNA), seperti DNA barcoding dan Polymerase Chain Reaction (PCR) biasanya digunakan untuk mengidentifikasi spesies elasmobranch ketika indikator morfologisnya sulit untuk diidentifikasi (Dudgeon et al. 2012; RodriguesFilho et al. 2012; Hanner et al. 2016; Hellberg et al. 2019; Appleyard et al. 2021).

Teknik DNA barcoding maupun mini-barcoding telah digunakan untuk mengidentifikasi spesies elasmobranch dalam berbagai produk komersial, termasuk sirip hiu kering, daging hiu, dan sup sirip hiu (Barbuto et al. 2010; Fields et al. 2015; Sembiring et al. 2015; Chuang et al. 2016; O'Bryhim et al. 2017; Steinke et al. 2017; Hellberg et al. 2019; Abdullah et al. 2020; Cardeñosa et al. 2020). Sejumlah penelitian juga telah membedakan spesies hiu menggunakan DNA barcoding yang dikombinasikan dengan analisis berbasis karakter, yang didasarkan pada ada tidaknya nukleotida spesifik yang ditentukan untuk diagnostik untuk spesies tertentu (Wong et al. 2009; Fields et al. 2015; VelezZuazo et al. 2015). Penelitian serupa terkait teknik DNA barcoding menggunakan primer ND4-F dan H12293-Leu-R untuk identifikasi hiu berjalan hewan endemik Halmahera, Maluku Utara berhasil mengidentifikasi kemiripan spesies Hemiscyllium halmahera sebesar 99,71-99,85\% (Madduppa et al. 2020)

Penelitian menggunakan teknik DNA barcoding dan primer spesifik pada spesies terdaftar CITES yang didaratkan di Tanjung Luar, NTB masih terbatas. Oleh karena itu, penelitian terkait autentikasi menggunakan teknik DNA barcoding menggunakan primer spesifik pada produk ikan hiu untuk mengidentifikasi jenis spesies yang dikategorikan terancam punah perlu dilakukan. 


\section{BAHAN DAN METODE Bahan dan Alat}

Bahan baku yang digunakan adalah daging ikan hiu segar yang di ambil dari TPI Tanjung Luar, Nusa Tenggara Barat. Bahan lain yang digunakan meliputi kit isolasi DNA QIAGEN DNeasy Blood \& Tissue), Kit PCR (KAPA Taq PCR KITs, KapaBiosystems, Wilmington, AS), $\mathrm{dd}_{2} \mathrm{O}$, primer spesifik Sphyrna lewini, Alopias pelagicus dan Carcharhinus falciformis, primer universal DNA barcoding FishF1R1 (Ward et al. 2005), marker $100 \mathrm{pb}$ plus DNA ladder (VIVANTIS, Selangor Darul Ehsan, Malaysia), cybergeen, agarosa $\left(\mathrm{SeaKem}{ }^{\circ} \mathrm{LE}\right.$ Agarose, Lonza, Rockland, ME USA), bufer TBE (AccuGENETM 10X TBE Buffer, Lonza, Rockland, ME AS), EDTA 0,05\% dan $\mathrm{Na}_{2} \mathrm{CO}_{3}$ $0,2 \%$, primer universal DNA barcoding FishF1R1 (Ward et al. 2005).

Alat yang digunakan meliputi microtubes TUBE-150-C (Extragene, Taichung, Taiwan) dan tabung PCR-02-C (Axygen, California, AS), pipet tips RC-10/20-L dan RC-250/20-C (Mettler Toledo, Bekasi, Indonesia), spin down (Corning, New York, AS), mikrosentrifugasi (Centurion Scientific 2041, Libertyville, AS), microwave (Sharp, Osaka, Jepang), timbangan digital (PHW 254, $\mathrm{ADAM}^{\oplus}$, Inggris), PCR (Applied Biosystem GeneAmp PCR System 9700, ThermoFisher Scientific (Vantaa, Finlandia), transiluminator-UV (Uvitec, Cambridge, Inggris), elektroforesis horizontal (HU6, SCIE-PLAS, Cambridge, Inggris), power supply (Peqlab, Erlangen, Jerman), dan nanodrop (Thermo Scientific, Vantaa, Jerman) serta BigDye ${ }^{\oplus}$ Terminator v3.1 cycle sequencing kit chemistry.

\section{Metode \\ Isolasi DNA sampel}

Sampel hiu diisolasi dengan mengikuti prosedur kit komersial Qiagen Dneasy Blood and Tissue untuk sampel ikan segar atau beku. Isolasi dengan Qiagen Dneasy Blood and Tissue kit menggunakan sampel sebanyak 0,05 g yang telah dihaluskan,

\section{Amplifikasi DNA barcoding}

Amplifikasi gen COI dilakukan menggunakan teknik PCR. Komponenkomponen yang digunakan pada proses PCR antara lain templat DNA, sepasang primer, $\mathrm{ddH}_{2} \mathrm{O}$, master mix yang terdiri dari dNTP, bufer PCR, $\mathrm{MgCl}_{2}$, dan enzim polimerase. Master mix PCR dibuat dengan volume total $25 \mu \mathrm{L}$ yang terdiri dari $2 \mu \mathrm{L}$ templat DNA, $8,5 \mu \mathrm{L}$ nuclease free water, $1 \mu \mathrm{L}$ primer forward, $1 \mu \mathrm{L}$ primer reverse, dan $12.5 \mu \mathrm{L}$ Taq polimerase. Kondisi suhu PCR pada tahap pra-denaturasi yaitu pada suhu $95^{\circ} \mathrm{C}$ selama 3 menit, tahap denaturasi $95^{\circ} \mathrm{C}$ selama 30 detik, penyepuhlindapan (annealing) pada $54^{\circ} \mathrm{C}$ selama 30 detik, extension pada $72^{\circ} \mathrm{C}$ selama 30 detik, dilanjutkan dengan final extension pada $72^{\circ} \mathrm{C}$ selama 5 menit. Tahap denaturation, annealing dan extension dilakukan sebanyak 35 siklus (Ward et al. 2005).

\section{Sekuensing}

Sekuensing dilakukan untuk menerjemahkan rangkaian untai DNA agar menjadi basa-basa nukleotida adenina, guanina, timina, sitosina (AGTC). Proses sekuensing dilakukan dengan metode Sanger et al. (1977) menggunakan templat DNA, primer, DNA polimerase, dan dideoxynucleotide (ddNTP) sebagai label basa terminator. Semua bahan tersebut yang telah diproses, akan dilakukan elektroforesis untuk menentukan urutan basa nukleotidanya sesuai dengan bobot molekulnya. Proses sekuensing dilakukan oleh perusahaan jasa pelayanan sekuensing yaitu PT Genetika Science, Jakarta.

\section{Analisis Data}

Analisis bioinformatika dilakukan untuk menginterpretasikan data yang diperoleh. Analisis bioinformatika dilakukan menggunakan BLAST (Basic Local Alignment Search Tool) (Altschul et al. 1990) agar mendapat kemiripan spesies berdasarkan kemiripan urutan basa-basa nukleotida. Perbandingan urutan basa-basa nukleotida dibandingkan dengan basis data referensi nukleotida yang berasal dari GenBank (https://www.ncbi.nlm.nih.gov/nucleotide/). Penyejajaran sekuensing dilakukan untuk menentukan jarak genetik dan hubungan kekerabatan sampel yang dikonstruksi dengan pohon filogenetik menggunakan piranti lunak ClustalW yang terintegrasi pada perangkat lunak MEGA 11 (Molecular Evalutionary 
Genetic Analysis). Jarak genetik dihitung menggunakan metode pairwise distance dan rancangan pohon filogenetik (1.000 kali ulangan) dan metode neighbor-joining tree bootstrap model Kimura Two parameter (Kimura 1980).

\section{HASIL DAN PEMBAHASAN Bioinformatika Sekuen DNA Sampel}

Tingkat homologi ditentukan dengan membandingkan data spesies di GenBank dan hasil sekuensing yang diperoleh dengan menggunakan Barcoding System for life data (BOLD) dan BLAST NCBI. Hasil identifikasi spesies ditunjukkan padaTable 1 .

Table 1 menunjukkan hasil analisis bioinformatika sampel dan data GenBank menggunakan BOLD Systems dan BLAST NCBI. BOLD adalah platform penyimpanan dan analisis data berbasis awan yang khusus ditujukan untuk DNA barcoding. Korelasi antara BLAST dan BOLD dengan pangkalan data GenBank dari gen fragmen COI adalah 99\%-100\%. Hasil analisis hiu sutra dengan nama ilmiah Carcharhinus falciformis teridentifikasi pada sampel hiu (A1 dan B1), yang memiliki 100\% kemiripan dengan BLAST NCBI dan BOLD Systems. Sampel C1 dan sampel D1, teridentifikasi dengan nama hiu martil (Sphyrna lewini). Tingkat homologi dari kedua sampel tersebut adalah $100 \%$ baik dari BLAST NCBI maupun BOLD Systems. Nilai persentase ini lebih tinggi dibanding pada penelitian Abdullah et al. (2020) yang memanfaatkan DNA Mini-barcodes dengan teknik spesies-spesifik pada produk olahan ikan hiu komersial yang menunjukkan tingkat homologi sebesar 98\% dari BLAST NCBI pada sampel hiu S. lewini dan menggunakan BOLD Systems sebesar 99,83\%. Hasil tersebut menunjukkan spesies yang teridentifikasi termasuk dalam daftar APPENDIX II dan kategori terancam punah (endangered) dalam IUCN red list yaitu hiu martil dan hiu sutra. Berdasarkan tingkat homologi untuk setiap sampel sekuens, dapat disimpulkan bahwa sampel A1, B1, C1, dan D1 pada penelitian ini teridentifikasi sebagai spesies hiu C. falciformis dan S. lewini.

Nilai E.value untuk semua sampel yang teridentifikasiadalah 0,0 . Nilai ini menunjukan bahwa sampel memiliki perbandingan spesies yang identik. Hasil ini sesuai dengan penelitian Abdullah et al. (2020) terkait autentikasi menggunakan DNA Mini-barcodes dengan teknik spesies-specsfik pada produk olahan ikan hiu komersial yang menunjukkan pada semua sampel yang diidentifikasi Nilai Expect value (E. value) yaitu 0. Menurut Drancourt et al. (2000) tingkat homologi dengan nilai 99\% menunjukkan kesesuaian antar spesies, tingkat homologi 97\% menunjukkan kesesuaian antar genus, dan homologi berkisar $89-93 \%$ menunjukkan kesesuaian antar famili. Menurut Isda dan Chaidamsari (2013) Analisis BLAST dilakukan dengan mempertimbangkan nilai parameter 150 atau lebih dan nilai E kurang dari 10-4 atau

Table 1 Species identification by BLAST and BOLD analysis

\begin{tabular}{lllrl}
\hline $\begin{array}{c}\text { Sample's } \\
\text { Code }\end{array}$ & \multicolumn{1}{c}{ Species ID } & $\begin{array}{c}\text { Homology } \\
(\%)\end{array}$ & E value & Access code \\
\hline \multicolumn{5}{c}{ BLAST NCBI } \\
\hline A1 & Carcharhinus falciformis & 100 & 0.0 & KX789508.1 \\
B1 & Carcharhinus falciformis & 100 & 0.0 & MN654308.1 \\
C1 & Sphyrna lewini & 100 & 0.0 & KF009669.1 \\
D1 & Sphyrna lewini & 100 & 0.0 & KF590254.1 \\
\hline \multicolumn{5}{c}{ BOLD systems } \\
\hline A1 & Carcharhinus falciformis & 100 & & MT152446 \\
B1 & Carcharhinus falciformis & 100 & - & MT152446 \\
C1 & Sphyrna lewini & 100 & - & MT324159 \\
D1 & Sphyrna lewini & 100 & - & MT324214 \\
\hline
\end{tabular}


mendekati 0 , dan tingkat homologi yang diperoleh cukup baik. Tingkat homologi yang baik ditandai dengan semakin tinggi skor (bits), dan nilai E yang semakin rendah maka tingkat homologinya semakin baik.

Jarak genetik adalah tingkat perbedaan genetik (perbedaan genom) dalam suatu populasi atau spesies yang diukur dengan variabel numerik. (Saitou dan Nei 1987). Jarak genetik dianalisis menggunakan model substitusi pairwise distance pada perangkat lunak MEGA. Jarak genetik dapat memperlihatkan kedekatan antara individu spesies secara genetik. Hasil analisis jarak genetik dapat dilihat pada Table 2. Jarak genetik dari sampel hiu dibandingkan dengan berbagai spesies hiu lainnya dari pangkalan data GenBank. Jarak genetik yang didapatkan dari GenBank yaitu berkisar 0,00-0,31. Nilai jarak genetik sampel hiu A1 dan B1 adalah 0,00 , nilai jarak genetik kedua sampel dengan database C. falciformis adalah 0,00. Nilai jarak genetik sampel hiu C1 dan D1 adalah 0,01 , nilai jarak genetik kedua sampel dengan database S. lewini adalah 0,01. Hasil tersebut menunjukkan sampel hiu $\mathrm{C} 1$ dan sampel hiu D1 masih memiliki kekerabatan spesies yang sama dengan S. lewini. Tallei et al. (2016) menjelaskan bahwa pada dua organisme semakin kecil nilai jarak genetik, maka semakin dekat hubungan kekerabatannya begitu pun sebaliknya.

Analisis pohon filogenetik digunakan untuk melihat tingkat hubungan kekerabatan antar sekuen berbeda yang saling berhubungan. Analisis pohon filogenetik menggunakan program MEGA 11. Metode yang digunakan pada konstruksi pohon filogenetik adalah metode Neighbour Joining Tree (NJT) menggunakan nilai bootstrap 1.000 kali. Kelebihan dari metode NJT yaitu mampu memperhitungkan jarak kekerabatan yang dapat dilihat dari besar kecilnya nilai bootstrap (Page dan Holmes 1998). Proses alignment menggunakan program ClustalW agar tingkat homologi antar urutan basa DNA yang dianalisis dapat ditentukan. Hasil pengujian pohon filogenetik Sphyrna lewini dan Carcharhinus falciformis dapat dilihat pada figure 2. Hasil dari pohon filogenetik menunjukan bahwa sampel hiu A1 dan B1 berada dalam satu clade dengan database GenBank Carcharhinus falciformis dengan nilai bootstrap sebesar 100\%. Begitu juga pada sampel C1 dan D1 yang berada dalam satu clade dengan spesies Sphyrna lewini dengan nilai bootstrap 100\%. Sedangkan pada penelitian Madduppa et al. (2020) pada hiu berjalan endemik halmahera menggunakan metode Maximum Likelihood menunjukkan Jarak genetic pada sampel spesies Hemiscyllium halmahera sangat dekat dengan nilai bootstrap 57-100\%. Bootstrap atau nilai bootstrap dapat digunakan sebagai tolak ukur dalam menentukan tingkat kepercayaan terhadap konstruksi pohon filogenetik. Tingginya nilai bootstrap maka tingkat kepercayaan pohon filogenetik hasil konstruksi tersebut semakin tinggi (Kumar et al. 2001). Menurut Lemey et al. (2009) untuk melakukan analisis NJT dan mendapatkan data yang relatif stabil dibutuhkan nilai bootstrap lebih besar dari 70 . Pohon filogenetik ikan hiu dapat dilihat pada Figure 2.

\section{KESIMPULAN}

Hasil autentikasi menggunakan metode DNA barcoding pada produk dari perairan NTB menunjukkan bahwa spesies yang teridentifikasi merupakan C.falciformis yang terdaftar dalam APPENDIX II dan S. lewini yang terdaftar dalam daftar merah IUCN spesies yang terancam punah (endangered). Autentikasi spesies pada produk hiu dengan pendekatan molekuler perlu dilakukan lebih lanjut, untuk menelusuri penggunaan spesiesspesies langka pada produk-produk hiu baik segar maupun olahan untuk membantu menegakkan kebijakan yang telah ditetapkan.

\section{UCAPAN TERIMA KASIH}

Terima kasih penulis ucapkan kepada kementerian RISTEKBRIN yang telah mendanai penelitian ini melalui Hibah Penelitian Terapan (PT) TA 2021 dengan nomor kontrak 1/E1/KP.PTNBH/2021.

\section{DAFTAR PUSTAKA}

Abdullah A, Elisa Ratih A, Aulia S, Rianti P, Nurhayati T, Mardiono Jacoeb A. 2020. Autentikasi produk olahan ikan hiu komersial menggunakan teknik species- 


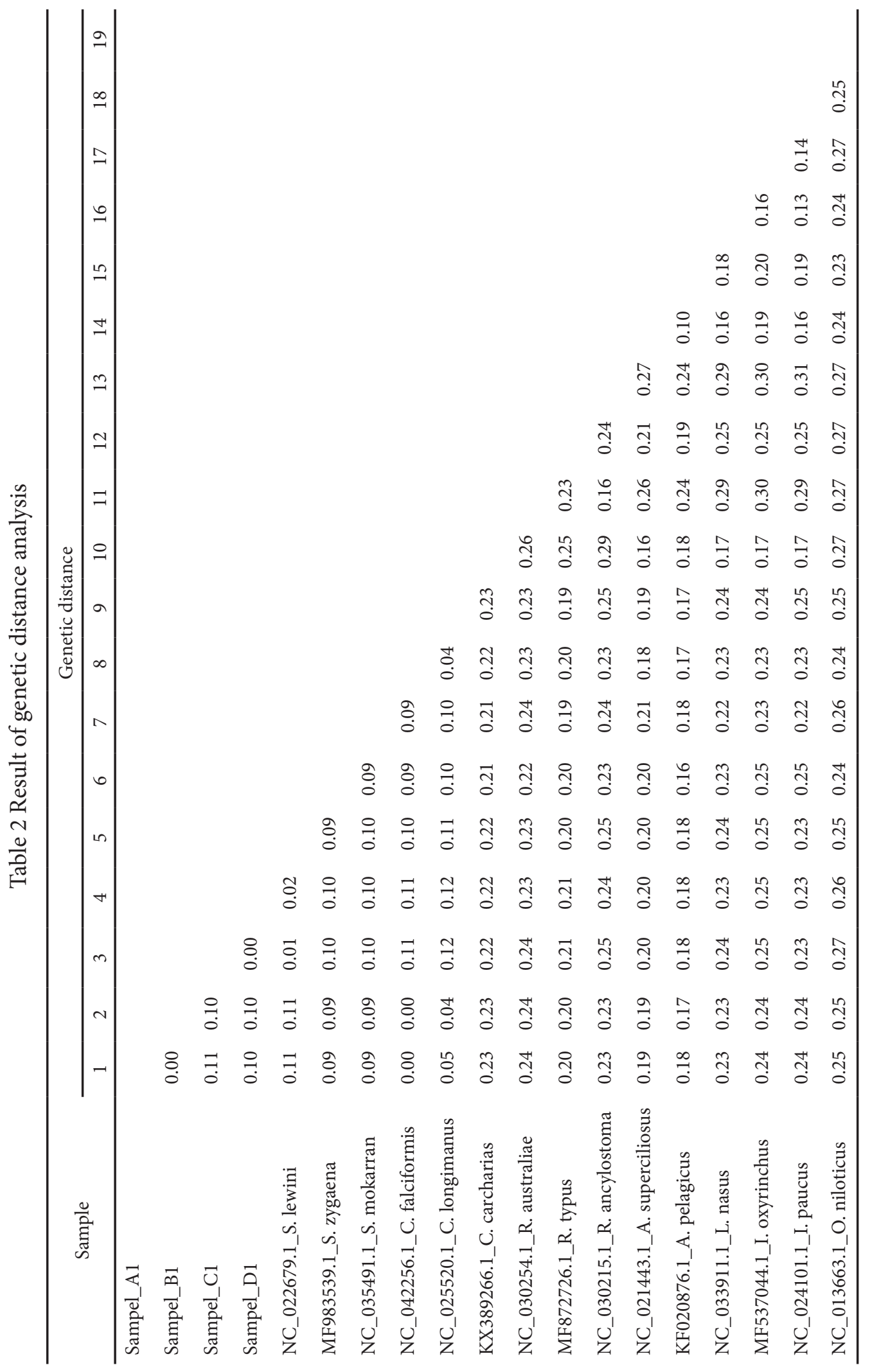




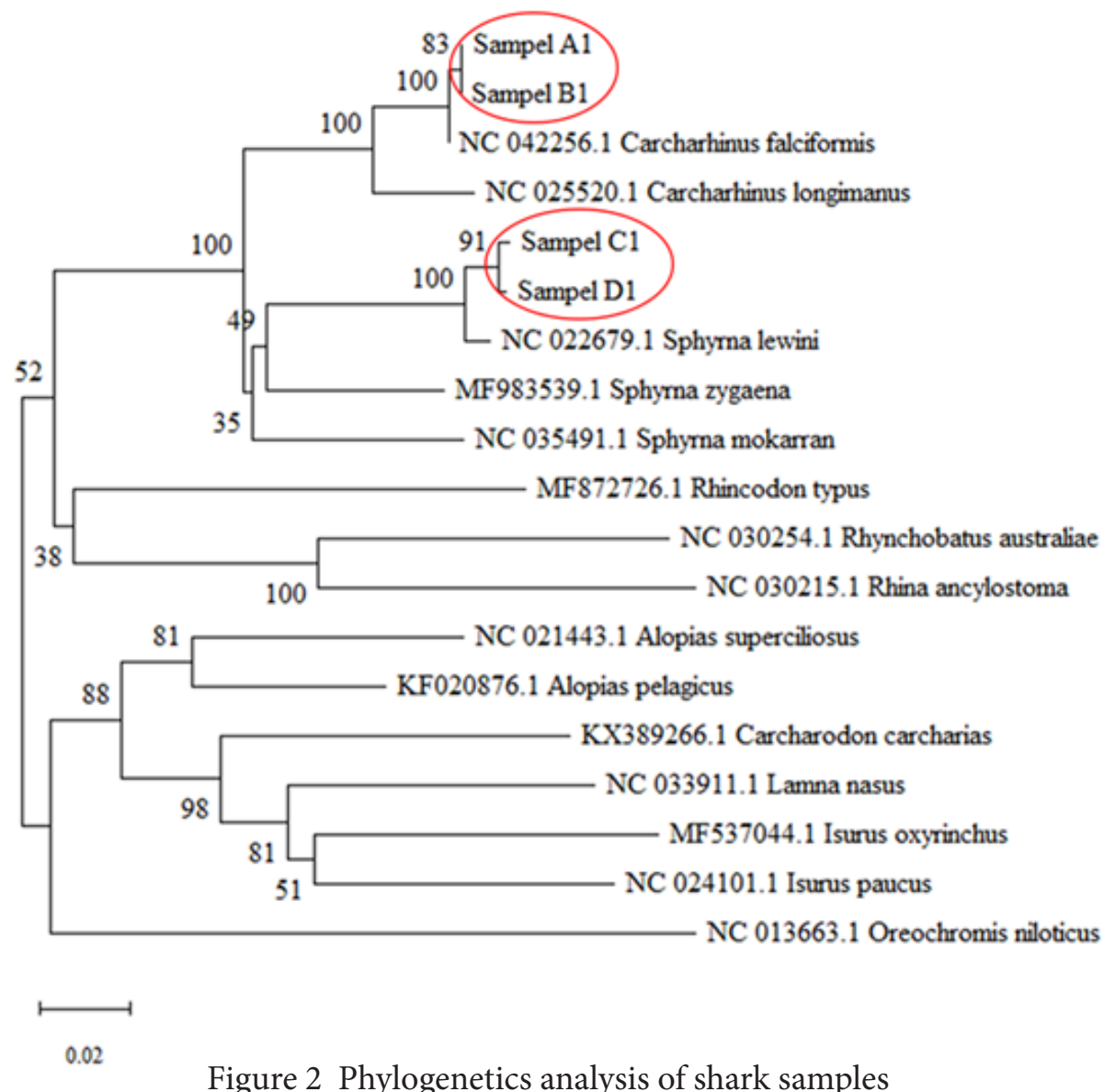

specific DNA Mini-barcodes. Jurnal Pengolahan Hasil Perikanan Indonesia. 23(2):383-391.

Altschul SF, Gish W, Miller W, Myers EW, Lipman DJ. 1990. Basic local alignment search tool. Journal of Molecular Biology. 215(3):403-410.

Appleyard SA, White WT, Vieira S, Sabub B. 2021. Publisher Correction: Artisanal shark fishing in Milne Bay Province, Papua New Guinea: biomass estimation from genetically identified shark and ray fins. Scientific Reports. 11(1):17962.

Barbuto M, Galimberti A, Ferri E, Labra M, Malandra R, Galli P, Casiraghi M. 2010. DNA barcoding reveals fraudulent substitutions in shark seafood products: The Italian case of "palombo" (Mustelus spp.). Food Research International 43(1):376-381.

Bräutigam A, Callow M, Campbell IR, Camhi MD, Cornish AS, Dulvy NK, Fordham SV, Fowler SL, Hood AR, McClennen C, Reuter EL, Sant G, Simpfendorfer CA,
Welch DJ. 2016. Global Priorities for Conserving Sharks and Rays A 20152025 Strategy.

Cardeñosa D, Fields AT, Shea SKH, Feldheim KA, Chapman DD. 2020. Relative contribution to the shark fin trade of Indo-Pacific and Eastern Pacific pelagic thresher sharks. Animal Conservation, siap terbit.

Chuang PS, Hung TC, Chang HA, Huang CK, Shiao JC. 2016. The species and origin of shark fins in Taiwan's fishing ports, markets, and customs detention: A DNA barcoding analysis. PLoS One. 11(1):1-13.

Dent F, Clarke S. 2015. State of the global market for shark products. FAO Fish and Aquacultures Technical Papers 590, siap terbit.

Drancourt M, Bollet C, Carlioz A, Martelin R, Gayral JP, Raoult D. 2000. 16S ribosomal DNA sequence analysis of a large collection of environmental and clinical unidentifiable bacterial isolates. Journal of Clinical Microbiology. 38(10):3623-3630. 
Dudgeon CL, Blower DC, Broderick D, Giles JL, Holmes BJ, Kashiwagi T, Krück NC, Morgan JAT, Tillett BJ, Ovenden JR. 2012. A review of the application of molecular genetics for fisheries management and conservation of sharks and rays. Journal of Fish Biology. 80(5):1789-1843.

Ferretti F, Worm B, Britten GL, Heithaus MR, Lotze HK. 2010. Patterns and ecosystem consequences of shark declines in the ocean. Ecology Letters. 13(8):1055-1071.

Fields AT, Abercrombie DL, Eng R, Feldheim K, Chapman DD.2015. A novel mini-DNA barcoding assay to identify processed fins from internationally protected shark species. PLoS One. 10(2):1-10.

Hanner RH, Naaum AM, Shivji MS. 2016. Conclusion: DNA-Based Authentication of Shark Products and Implications for Conservation and Management. Elsevier Inc.

Hellberg RS, Isaacs RB, Hernandez EL. 2019. Identification of shark species in commercial products using DNA barcoding. Fisheries Research. 210 April 2018:81-88.

Isda MN, Chaidamsari T. 2013. Analisis sekuen gen proteinase inhibitor (TcPIN) terkait dengan ketahanan terhadap penggerek buah kakao. Prosiding Semirata FMIPA Universitas Lampung.

Kumar S, Tamura K, Jakobsen IB, Nei M. 2001. MEGA2: molecular evolutionary genetics analysis software. Bioinformatics. 17(12):1244-1245.

Madduppa H, Putri ASP, Wicaksono RZ, Subhan B, Akbar N, Ismail F, Arafat D, Prabuning D, Sani LMI, Srimariana ES, et al. 2020. Morphometric and DNA barcoding of endemic halmaheran walking shark (Hemiscyllium halmahera, Allen, 2013) in North Maluku, Indonesia. Biodiversitas. 21(7):3331-3343.

Marshall LJ, Barone M. 2016. SharkFin Guide: identifying sharks from their fins.

Muttaqin E, Simeon BM, Ichsan M, Dharmadi, Prasetyo AP, Booth H, Yulianto I, Friedman K. 2018. The scale, value and importance of non-fin shark and ray commodities in Indonesia. Food and Agriculture Organization of the United
Nations, Ministry of Marine Affairs and Fisheries, Wildlife Conservation Society.

O'Bryhim JR, Parsons ECM, Lance SL. 2017. Forensic species identification of elasmobranch products sold in Costa Rican markets. Fisheries Research. 186:144-150.

Rodrigues-Filho LF, Pinhal D, Sodré D, Vallinoto M. 2012. Shark DNA Forensics: Applications and Impacts on Genetic Diversity. Analysis of Genetic Variation in Animals. Mahmut Caliskan (ed.).

Sanger F, Nicklen S, Coulson AR. 1977. DNA sequencing with chain-terminating inhibitors. Proceedings of the National Academy of Sciences of the United States of America. 74(12):5463-5467.

Sembiring A, Pertiwi NPD, Mahardini A, Wulandari R, Kurniasih EM, Kuncoro AW, Cahyani NKD, Anggoro AW, Ulfa M, Madduppa H, Carpenter KE, Barber PH, Mahardika GN. 2015. DNA barcoding reveals targeted fisheries for endangered sharks in Indonesia. Fisheries Research. 164:130-134.

Simeon BM, Agustina S, Muttaqin E, Yulianto I, Ichsan M, Muhsin. 2017. Laporan teknis: Pemantauan hasil tangkapan hiu dan pari di Tanjung Luar, Provinsi Nusa Tenggara Barat. Mei 2021:14.

Steinke D, Bernard AM, Horn RL, Hilton P, Hanner R, Shivji MS. 2017. DNA analysis of traded shark fins and mobulid gill plates reveals a high proportion of species of conservation concern. Scientific Reports. 7(1):9505.

Velez-Zuazo X, Alfaro-Shigueto J, Mangel J, Papa R, Agnarsson I. 2015. What barcode sequencing reveals about the shark fishery in Peru. Fisheries Research. 161:34-41.

Ward RD, Zemlak TS, Innes BH, Last PR, Hebert PDN. 2005. DNA barcoding Australia's fish species. Philosophical Transactions of the Royal Society $B$. 360(1462):1847-1857.

Wong EH-K, Shivji MS, Hanner RH. 2009. Identifying sharks with DNA barcodes: assessing the utility of a nucleotide diagnostic approach. Molecular Ecology Resources. 9(s1):243-256. 